\title{
Ethics Code Awareness, Usefulness and Professionalism of Malaysian Journalists
}

\author{
Quah Chun Hoo and Leong Shi Yeing \\ Universiti Sains Malaysia, Malaysia \\ Guok Eng Chai \\ GEC Management Consultant, Malaysia
}

\begin{abstract}
The purpose of this research is to explore: a) how Malaysian journalists with idealistic and relativistic orientations perceive their ethical codes, the code's usefulness and their professionalism? and b) is there any significant difference amongst Malaysian journalists from different language dailies and medium of education in terms of their idealism and relativism? Data was collected from 145 journalists from different dailies in Ipoh and Penang, within Peninsular Malaysia using "convenience" sampling. A total of 128 responses (88.3\% return rate) were received. Malaysian journalists, who scored higher in idealism and lower in relativism, were more inclined to adhere to their codes of ethics compared to their counterparts, who were higher in relativism and lower in idealism. In addition, it was found that respondents' profile such as type of language daily and journalists' medium of education had no impact on journalists' ethical judgments.
\end{abstract}

\section{Keywords}

Journalistic code of ethics, code awareness, code usefulness, professionalism, idealism, relativism

\section{Introduction}

Codes of ethics are being increasingly adopted by many companies as well as professionals and associations to guide the ethical behaviour of their employees and members in their daily activities. According to Kaptein (2004) fifty eight percent of the 100 largest companies in the world use ethical codes. Codes articulate ethical parameters of the organization - what is acceptable and what is not? (Stevens, 2008, p.1). Wotruba et al. (2001) reported that the usefulness of codes of ethics as a guide to managers in their behaviour and decision making is strengthened as managers become more aware of the specific contents of the code. This notion is consistent with earlier assertions that employees must be familiar with code contents before the code can affect ethical behaviour (Sims, 1991; Dean, 1992).

Whilst the usefulness of code of ethics cannot be over-emphasized (Ford \& Richardson, 1994; Wotruba, 1995; Casel et al., 1997; Trevino et al., 1999; Chonko et al., 2003), codes of ethics are not the sole factor influencing ethical decisions. Ethical decisions are also dependent on the personal values of the decision maker. Two personal values that have received attention in the literature are

Copyright (C) 2010 Victoria University. This document has been published as part of the Journal of Business Systems, Governance and Ethics in both online and print formats. Educational and non-profit institutions are granted a nonexclusive licence to utilise this document in whole or in part for personal or classroom use without fee, provided that correct attribution and citation are made and this copyright statement is reproduced. Any other usage is prohibited without the express permission of the publisher. relativism and idealism (Schlenker \& Forsyth, 1977; Forsyth, 1980). Tansey et al. (1994) contended that ethical models should include the traits of idealism and relativism. Idealism refers to the tendency to avoid harming others when making moral judgment, whilst relativism refers to the tendency to disregard universal moral rules when making moral judgment (Chonko et al., 2003). 
The ethical conduct of journalists has come under public scrutiny in recent years as journalists and public are more concerned with the flow of information due to freedom of press. Svensson \& Wood (2008 p. 310) mentioned that "the emphasis that media put on items that they consider news worthy can change opinion and move support behind hitherto unknown and unheralded courses". Hence, code of ethics can help journalists make sound decisions about the many ethical problems they may encounter in their work.

Journalists are restricted from reporting certain sensitive issues that may harm governments and political parties. This kind of political control has left the public with less opportunity to obtain truthful information and made it difficult for journalists to report the truth. Often, journalists have to serve other party interest to report the news the way their political masters deem fit, instead of the actual facts. This view is shared by Swenson and Wood (2008, p. 310) who stated that the media creates expectations of business for us as a society by choosing, which issues to highlight for our consumption and which issues to downplay or even ignore. However, Musa \& Domatob (2007) argued that to be relevant, development journalists must be concerned with credibility which will win the respect of political leaders and citizens alike. They added that journalists must become truth tellers for the common good and differentiate between partnering with political leaders to promote national development and becoming instruments of political manipulation.

Although there has been an explosion of scholarly interest in journalistic ethics in recent decades (Christians, 1995), much of the resulting literature review describes the ethics, values, responsibility or roles of particular types of journalists (Harcup, 2002; Musa \& Domatob, 2007). There is a need for ethics research that focuses on the relationship of journalists' moral values (idealism and relativism) and their code of ethics. Adapting the work of Chonko et al. (2003) in the context of journalism in Peninsular Malaysia this research primarily attempts to investigate empirically whether the decision making of journalists vary across the following dimensions: awareness of their code of ethics, usefulness of the code, idealism, relativism and journalists' professionalism.

Hence, this research addresses the following broad questions:

- How do Malaysian journalists with idealistic and relativistic orientations perceive their ethical codes, the code's usefulness and their professionalism?"; and

- Is there any significant difference among Malaysian journalists from different language dailies and medium of education in terms of their idealism and relativism?

\section{Journalists' Ethical Dilemmas: The Malaysian Perspective}

Malaysia's journalists' code of ethics was formulated by National Union of Journalists Malaysia (NUJM) in 1962. The NUJM is the only organization of working journalists in the country representing the industrial, social and welfare interest of some 1,400 journalists. It was formed on August 30, 1962. NUJM is the sole authority to negotiate and determine the proper rates of remuneration and other terms and conditions of employment for journalists in the various publishing houses which produce Malay, English and Chinese newspapers and periodicals (www.NUJM.org). There is a plethora of publications, about a dozen or so newspapers in four different languages, but no free press. Until the advent of internet, the government had a complete monopoly on the distribution of information. Whilst this technology has enabled Malaysians finally to break through government barriers, they are still no nearer to breaking its monopoly on power (Steven Gan, 2002).

There is no, and there never has been absolute freedom of the press in Malaysia and Singapore. There is not even relative freedom of the press in Vietnam, China or North Korea, since in communist or socialist states, all media outlets are owned and operated by either the socialist state or the ruling Communist Party (Abaya, 2006). Musa \& Domatob (2007, p. 322) stated that "from Malaysia to Mexico and from the Carribean to Iran, the media became an organ of the post-colonial state and the new regime in power". Wong (2004) found that development journalists in Malaysia and Singapore tend to support the ruling party during elections.

The state of control of media in Malaysia can be also be traced back to the restructuring of the economy of the country through the New Economic Policy (NEP), which produced a group of 
politically well connected Bumiputera and non-Bumiputera business people (Wang, 2001). Mainstream media is controlled by main component parties in Barisan Nasional (MCA, UMNO, and MIC). Besides, ownership of media is also controlled by license and laws such as Printing Presses and Publication Act 1984 (PPPA), Internal Security Act 1960 (ISA), Official Secret Act 1972 (OSA), Broadcasting Act 1998 and Sedition Act 1948. Hence, through this kind of restriction, media is controlled indirectly. This causes journalists' lack of freedom to report the truth.

The acquisition of the publishing companies was intended to control the editorial content of the newspapers. The ownership of New Straits Time Press and Utusan Melayu Press gives the United Malays National Organization (UMNO), Malaysia's ruling party, control of the major newspapers in Malaysia. Apart from UMNO having substantial interests in the publishing industry, the other two main component parties, the Malaysian Chinese Association (MCA) and the Malaysian Indian Congress (MIC) also control a substantial part of the mainstream media (Wang, 2001). The press in a situation of control becomes inept in playing the adversarial role of watchdog. Consequently, this situation makes its difficult for citizens to exercise their right to information and their right to making informed choices (Wang, 2001).

There is a general lack of freedom for journalists in Malaysia to report the truth as most of the presses are controlled by one or other political parties. Most of the news has to be sieved first before being reported to the public. Hence, journalists are faced with an ethical dilemma whether to report the truth or to follow the interest of their political masters. Journalists play an important role to inform and report the news to the public for greater understanding on latest issues. Their responsibility is to gather information and report it to the public. They have to act ethically and be professional in reporting news exactly and correctly. Although journalists may not consciously be distorting their reporting, they may, nonetheless, be reporting the events in a manner conducive to the interests and values of a particular section or society.

Irrespective of the political, social and economic changes that are taking place, Malaysian journalists should meet the expectations of the society by being committed to their roles as truth tellers, civil advocates, investigative watchdogs, and economic boosters and liberators as cited by Musa \& Domatob (2007). Malaysia being a democratic society and in the light of the National Integrity Plan which stresses on trustworthiness, transparency and accountability, the watchdog role of journalists is becoming more critical.

\section{Code of Ethics}

Loe et al. (2000), in their review of the ethics literature, report a wide variety of conclusions concerning the impact of codes of ethics. Both Dean (1992) and Sims (1991) reported that employees must be familiar with code contents before the code can impact awareness and behaviour. Marshall et al. (1998) presented mixed results regarding the impact of codes on ethical behaviour, whilst Morris et al. (1996) discovered that codes were ineffective and they further noted that belief in code effectiveness declines as standards decline. Ekin \& Tezolmez (1999) reported that personal codes were more effective in influencing behaviour than company codes. Weeks \& Nantel (1992) also found codes to be ineffective except when the codes are being well communicated.

Maes et al. (1998) stated that codes represent an attempt to initiate thinking about unethical behaviour. McDonald (2000) called for codes to be written in simple terms and he further clamoured that codes must specify the commitment of the organization to employees, not just the employees' responsibilities concerning ethical performance. Strutton et al. (1997) examined the impact of codes of ethics vis-à-vis customer expectations and also contended that codes, by themselves are not effective in influencing behaviour. Schwartz (2000) contended that codes are ineffective systems of control but in a later study (2001) concluded that they are effective in some situations and failed in others.

In spite of the varied findings on code impacts, Loe et al. (2000) asserted that codes do influence ethical behaviour and the level of awareness of ethical issues. As mentioned earlier, Wotruba et al. (2001) discovered that the usefulness of codes of ethics by managers as a tool for guiding behaviour and decisions is strengthened as managers become familiar with the specific contents and intentions of codes. However, other studies (Fisher, 2001; Somers, 2001; Trevino \& Weaver, 2003; Chonko et al., 
2003; Schwartz, 2001; Adam \& Rachman-Moore, 2004; O'Dwyer \& Madden, 2006; Vitell \& Encarnacion, 2006) provided evidence of code effectiveness in terms of playing a role in impacting employee behaviour and perceiving right ethical actions. A more recent study by Stevens (2008) indicated that corporate ethical codes can be effective instruments for moulding employee behaviour and guiding ethical decision-making when they are embedded in the organizational culture and communicated effectively.

Details of the Journalistic Code of Ethics in Malaysia are as follows:

(a) Respect for truth and for the right of the public to truth is the first duty of journalists. To defend the freedom of the press, to deal with the conduct of its members and to maintain high ethical standards in journalism

(b) In pursuance of this duty he will defend the twin principles: freedom in honest collection and publications of news and the right of fair comment and criticism

(c) The journalist reports only in accordance with the facts of which he knows the origin. He will not suppress essential information or falsify documents

(d) He will use only fair methods to obtain news, photographs and documents

(e) Any published information which is found to be harmfully inaccurate he will do his utmost to rectify

(f) He will observe professional secret regarding the source of information obtained in confidence

(g) He will regard as grave professional offences the following: plagiarism, calumny, slander, libel and unfounded accusations, and the acceptance of a bribe in any form in consideration in either publication or suppression, and

(h) He recognizes in professional matters, the jurisdiction of his colleagues' only, he excludes every kind of interference by governments or others (www.NUJM.org).

\section{Professionalism}

Professional ethics are measured using the scenario technique (Hunt \& Chonko, 1985; Singhapakdi \& Vitell, 1992). The use of scenario to determine professional ethics allow for the inclusion of background information and detail in an ethical situation (Tsalikis \& Fritzsche, 1989).

Tsalikis \& Fritzsche (1989) stated that there are two ethical standards: personal and professional, with the personal level of ethics being stricter than the professional level (since the professional level may be compromised because of the need to succeed and to meet corporate goals).

The professionalism dimension considers norms and values of the journalistic profession at large, a dimension that goes beyond a specific newsroom. This dimension is shaped by professional journalists' organization, education and cross organizational culture that is built and shared during the journalists' careers.

Like other employees, journalists are caught in dialectic between their professional ideals and the profit-motivated concerns that keep news organizations in business and financially viable (Berkowitz, 1994). Although journalists are often depicted as independent, morally virtuous, and acting in the name of the public good (McManus, 1997), Borten (2000) argued that journalists are trapped in a dialectic between professional codes and norms less feasible. Although some writers have viewed journalism as either a profession or a professionalizing occupation (Abbot, 1988), it has often been seen as lacking several pre-requisites of professionalism (Porter, 1968). In this study, we posit that journalists should act professionally, taking guidance from their codes.

\section{Idealism and Relativism}

According to Forsyth (1980), idealism and relativism are individual differences that influence judgments of moral issues. Idealism and relativism have exhibited their explanatory power of ethical decisions (Singhapakdi, et al., 1999; Marta et al., 2001). Forsyth \& Berger (1992) mentioned that 
idealism and relativism are not opposite concepts; rather they are independent concepts of beliefs. In other words, idealism focuses on "unselfish" concern for others, whilst relativism emphasizes on the best of alternatives. Relativistic individuals base their evaluation on skepticism and consider situations in terms other than ethical principles (Forsyth \& Berger, 1992). For relativistic individuals, standards of what is right and wrong can be changed according to situation.

Even though idealism and relativism were not conceptualized as contrasting, many researchers have found contrasting relationships of idealism and relativism with ethics constructs (Singhapakdi et al., 1996; Etheredge, 1999; Marta et al., (2001), Forsyth's (1981). These findings imply that idealist viewed the world differently from relativists. In the sales profession, Barnett et al., (1994) discovered that idealists and relativists differed in their judgments about many ethical issues. Generally, idealists tend to judge ethically ambiguous actions more harshly than relativists (Bass, et al., 1998). Relativists' judgments of the morality of actions depended on the specifics of a situation and the individual involved (Chonko et al., 2003).

Since one purpose of codes of ethics is to impact employee behaviour (Dean, 1992), it would seem that relativist would find codes less useful than idealists. Trevino (1990) suggested that codes must be distributed to and understood by employees and firmly enforced. Under such circumstances, code content becomes institutionalized in behaviour and may be viewed as too restrictive by employees with a relativist orientation.

Chonko et al. (2003) explored whether the impact of code awareness on code usefulness differed between direct selling executives in U.S. with relativist versus idealists personal values. Chonko et al.'s (2003) findings indicated ethics code awareness is negatively related to relativism and not related to idealism. This suggests that more relativistic respondents are less familiar with codes of ethics compared to more idealistic counterparts. Furthermore, the findings showed that ethics code usefulness is negatively related to relativism and positively related to idealism. Thus, higher idealistic executives view codes of ethics as more useful, whereas higher relativistic executives view codes as less useful. Hence, the following hypotheses were tested in the context of journalists' profession in Malaysia:

$\mathrm{H}_{1 \mathrm{a}}$ : Journalists' awareness of their ethics code is positively related to idealism.

$\mathrm{H}_{1 \mathrm{~b}}$ : Journalists' awareness of their ethics code is negatively related to relativism.

$\mathrm{H}_{2 \mathrm{a}}$ : Journalists' perception of usefulness of their ethics code is positively related to idealism.

$\mathrm{H}_{2 b}$ : Journalists' perception of usefulness of their ethics code is negatively related to relativism.

$\mathrm{H}_{3 \mathrm{a}}$ : Journalists' professionalism is positively related to idealism.

$\mathrm{H}_{3 \mathrm{~b}}$ : Journalists' professionalism is negatively related to relativism.

$\mathrm{H}_{4 \mathrm{a}}$ : There is no significant difference among journalists from different language dailies in terms of idealism and relativism.

$\mathrm{H}_{4 \mathrm{~b}}$ : There is significant difference among journalists from different language dailies in terms of idealism and relativism.

$\mathrm{H}_{5 \mathrm{a}}$ : There is no significant difference among journalists with different education background in terms of idealism and relativism.

$\mathrm{H}_{5 \mathrm{~b}}$ : There is significant difference among journalists with different education background in terms of idealism and relativism.

\section{Research Methodology}

\section{Sample}

Journalists were asked to respond to a survey questionnaire distributed to them via "convenience" sampling. The respondents, who worked for different dailies in Ipoh and Penang, in Peninsular Malaysia were selected based on convenience. A survey questionnaire was distributed to each of the 
145 journalists or respondents who participated in the study. The number of useable responses received was 128 , constituting a response rate of 88.3 percent. A description of the sample is shown in Table 1.

Table 1 - The Sample: Descriptive Statistics

\begin{tabular}{|l|l|}
\hline Respondents: & Journalists from different dailies \\
\hline Sample Size: & 145 \\
\hline Response: & $128(88.3 \%)$ \\
\hline Age: & $80 \%$ below 36 years of age \\
\hline Gender: & $52 \%$ female \\
\hline Education: & $45 \%$ Chinese medium \\
\hline Ethnicity: & $59 \%$ Chinese \\
\hline Religion: & $34 \%$ Christians \\
\hline $\begin{array}{l}\text { Length of Service/ } \\
\text { Experience: }\end{array}$ & $60 \%$ with length of service/experience 5 years and below \\
\hline Type of Daily: & $48 \%$ English \\
\hline
\end{tabular}

\section{Measure}

Idealism and Relativism - These variables were measured using Forsyth's 1980 Ethical Position Questionnaire (EPQ) designed to measure individual differences in idealism and relativism. Idealism is defined as the degree to which an individual believes that ethically correct actions will consistently produce desirable outcomes, whereas, relativism is defined as the degree to which an individual cognitively accepts/rejects universal moral perceptions as the basis for ethical decisions (Chonko et al., 2003). The idealism and relativism scales each contained 10 and 8 items respectively. These scales have proven to be reliable in several studies (Vitell, et al., 1991) based on Cronbach's Alpha reliability coefficient.

Code awareness and usefulness - This study adapted two scales taken from Wotruba et al. (2001). Ethics code awareness (3 items) is defined as the extent to which an individual has knowledge of ethical code content, whilst, ethics code usefulness (2 items) is defined as the extent to which an individual considers ethical code contents to be useful in daily activities (Chonko et al., 2003).

Professionalism - The professionalism dimension focuses on the norms and values of the journalists' profession at large, a dimension that goes beyond a specific newsroom. It comprises 6 items adapted to suit the purpose of this research.

Reliability - The closer the Cronbach's alpha reliability coefficient is to 1.0, the more reliable it is. Generally, reliabilities less than 0.6 are considered to be poor, those in the range of 0.7 are acceptable, and those over 0.8 are good (Sekaran, 2000).

Table II - Pearson Matrix, Reliability Analysis and Descriptive Statistics

\begin{tabular}{|c|c|c|c|c|c|c|c|}
\hline Variable & $\begin{array}{c}\text { Code } \\
\text { Awareness }\end{array}$ & $\begin{array}{c}\text { Code } \\
\text { Usefulness }\end{array}$ & Professionalism & Idealism & Relativism & Mean & S.D \\
\hline Code Awareness & \#0.782 & & & & & 3.23 & 0.68 \\
\hline Code Usefulness & $0.240^{* *}$ & \#0.644 & & & & 3.37 & 0.44 \\
\hline Professionalism & $0.699 * *$ & $0.182^{*}$ & ${ }^{\#} 0.713$ & & & 3.64 & 0.49 \\
\hline Idealism & $0.521 * *$ & 0.031 & $0.510^{* *}$ & $\# 0.800$ & & 3.70 & 0.52 \\
\hline Relativism & $-0.239^{* *}$ & -0.011 & -0.158 & -0.105 & ${ }^{\#} 0.642$ & 2.25 & 0.37 \\
\hline
\end{tabular}

${ }^{\#}$ Cronbach alpha values in diagonal $\quad{ }^{*} \mathrm{p} \leq 0.05 \quad * * \mathrm{p} \leq 0.01$ 
Table II shows all the alpha coefficients are above 0.6 ; hence all the measures employed in this study are reliable. Idealism recorded the highest reliability of 0.800 and relativism registered the lowest reliability (0.642). However, one item each from code awareness and code usefulness were deleted to increase the reliability of scale.

For code awareness, item that was deleted was I consider myself knowledgeable of content of the journalistic code of ethics. For code usefulness, item that was deleted was The NJU's code of ethics has not helped journalists to be more ethical.

Similarly, two items from professionalism and relativism were deleted to enhance the reliability of scale. For professionalism, items that were deleted include $I$ would not act according to my logic and feelings as well as my decisions are based on the journalistic code of ethics. For relativism, items that were deleted include No rule concerning lying can be formulated; whether a lie is permissible or not permissible totally depends upon the situation as well as whether a lie is judged to be immoral depends upon the circumstances and the actions. Overall, all the variables that were analysed were reliable.

\section{Instrument Development}

The survey questionnaire comprises three sections. Section One focuses on journalists' perceptions towards ethics code awareness, ethics code usefulness, and journalists' professionalism. The response scale, based on a five-point Likert scale where $1=$ strongly disagree, $2=$ disagree, $3=$ neutral, $4=$ agree, $5=$ strongly agree was used to gauge perceptions. Section Two which measured journalists' idealistic and relativistic orientations also used a five-point Likert scale similar to that of Section One to measure idealism and relativism. Finally, Section Three captured the demographics or respondents' profile which consisted of gender, age, ethnicity, religion, length of service/experience, type of daily, and education medium.

\section{Analysis}

All the statistics in this study were computed using Statistical Package for Social Sciences (SPSS) version 14.0. Pearson's Correlation, the Cronbach alpha reliability coefficients and descriptive statistics for ethics code awareness, ethics code usefulness, professionalism, idealism and relativism are presented in Table II. Test of difference statistics using one-way ANOVA technique are shown in Tables III and IV.

Table III - One-Way ANOVA Statistics for Idealism \& Relativism Based on Type of Language Daily

\begin{tabular}{|l|c|c|c|c|c|c|c|c|}
\hline \multirow{3}{*}{ Variable } & \multicolumn{5}{|c|}{ TYPE OF LANGUAGE DAILY } & \multirow{2}{*}{ F Value } & \multirow{2}{*}{ Significance } \\
\cline { 2 - 7 } & \multicolumn{2}{|c|}{$\begin{array}{c}\text { English Daily (n= } \\
\text { 61) }\end{array}$} & \multicolumn{2}{|c|}{$\begin{array}{c}\text { Chinese Daily (n= } \\
\text { 46) }\end{array}$} & \multicolumn{2}{|c|}{$\begin{array}{c}\text { Malay Daily (n }= \\
\text { 21)* }\end{array}$} & \\
\cline { 2 - 7 } & Mean & $\begin{array}{c}\text { Std. } \\
\text { Dev. }\end{array}$ & Mean & $\begin{array}{c}\text { Std. } \\
\text { Dev. }\end{array}$ & Mean & $\begin{array}{c}\text { Std. } \\
\text { Dev. }\end{array}$ & \\
\hline Idealism & 3.76 & .607 & 3.60 & .461 & 3.80 & .306 & 1.726 & 0.182 \\
\hline Relativism & 2.21 & .410 & 2.31 & .348 & 2.24 & .368 & 0.939 & 0.394 \\
\hline
\end{tabular}

*The sample for this group is $<30$, hence the results may be unreliable

Table IV - One-Way ANOVA Statistics for Idealism \& Relativism Based on Type of Education Medium

\begin{tabular}{|l|c|c|c|c|c|c|c|c|}
\hline \multirow{3}{*}{ Variable } & \multicolumn{5}{|c|}{ TYPE OF EDUCATION MEDIUM } & \multirow{2}{*}{ F Value } & \multirow{2}{*}{ Significance } \\
\cline { 2 - 7 } & English (n= 36) & \multicolumn{2}{|c|}{ Chinese (n= 58) } & \multicolumn{2}{|c|}{ Malay (n= 34) } & \\
\cline { 2 - 7 } & Mean & $\begin{array}{c}\text { Std. } \\
\text { Dev. }\end{array}$ & Mean & $\begin{array}{c}\text { Std. } \\
\text { Dev. }\end{array}$ & Mean & $\begin{array}{c}\text { Std. } \\
\text { Dev. }\end{array}$ & & \\
\hline Idealism & 3.61 & .481 & 3.69 & .485 & 3.85 & .599 & 1.951 & 0.146 \\
\hline Relativism & 2.24 & .362 & 2.30 & .353 & 2.17 & .396 & 1.247 & 0.291 \\
\hline
\end{tabular}




\section{Results}

Our first hypothesis of the study addressed the question, "Does ethics code awareness differ between idealist and relativist journalists?" The results in Table II revealed that awareness is positively related to idealism $(\mathrm{r}=0.521)$ and negatively related to relativism $(\mathrm{r}=-0.239)$. Thus, both $\mathrm{H}_{1 \mathrm{a}}$ and $\mathrm{H}_{1 \mathrm{~b}}$ were supported.

With regard to our second hypothesis which addressed the question "Does the perceived usefulness of ethics code differ between idealist and relativist journalists?", the results indicated that usefulness is not related to idealism $(\mathrm{r}=0.031)$ and relativism $(\mathrm{r}=-0.011)$. Thus, both $\mathrm{H}_{2 \mathrm{a}}$ and $\mathrm{H}_{2 \mathrm{~b}}$ were not supported.

As for our third hypothesis which addressed the question, "Does idealist and relativist journalists' differ in their professionalism? the results showed that professionalism was positively related to idealism $(\mathrm{r}=0.510)$ and not related to relativism $(\mathrm{r}=-0.158)$. Thus, $\mathrm{H}_{3 \mathrm{a}}$ was supported but $\mathrm{H}_{3 \mathrm{~b}}$ was not.

Our fourth hypothesis addressed the question "Is there any significant difference among journalists from different language dailies in terms of idealism and relativism?" The result in Table III indicate that there was no significant difference as shown by the $\mathrm{F}$ value $=1.726, \mathrm{p}=0.182$ for idealism and the $\mathrm{F}$ value $=0.939, \mathrm{p}=0.394$ for relativism (significance level is $\mathrm{p} \leq 0.05$ ). Hence, null hypothesis $\mathrm{H}_{4 \mathrm{a}}$ was accepted and alternate hypothesis $\mathrm{H}_{4 \mathrm{~b}}$ was rejected.

Finally, our fifth hypothesis addressed the question, "Is there any significant difference among journalists with different education medium in terms of idealism and relativism?" The results in Table IV showed that there was no significant difference as evidenced by the $F$ value $=1.951, p=0.146$ for idealism and relativism $(\mathrm{F}$ value $=1.247, \mathrm{p}=0.291)$. Thus, null hypothesis $\mathrm{H}_{5 \mathrm{a}}$ was accepted and alternate hypothesis $\mathrm{H}_{5 \mathrm{~b}}$ was rejected.

\section{Discussion}

Overall, our findings corroborated with those of Forsyth et al.'s (1988) and Chonko, et al.'s (2003) in that idealists and relativists have divergent perceptions towards codes of ethics. Specifically, our results in Table II indicate that there is significant positive relationship between code awareness and idealism and significant negative relationship between code awareness and relativism. This implies that the idealist journalist is more likely to be aware of the code contents, whereas the relativist journalist is less likely to be aware of the code contents. However, this finding only partially supported Chonko et al.'s (2003) findings that there is significant negative relationship between ethics code awareness and relativism and no significant positive relationship between awareness and idealism.

Besides, our results also indicated that there was no significant positive relationship between code usefulness and idealism as well as no significant negative relationship between code usefulness and relativism. However, this finding is contrary to that of Chonko et al.'s (2003) findings, who reported significant positive relationship between code usefulness and idealism as well as significant negative relationship between code usefulness and relativism. As mentioned by Chandra Muzaffar (1986) and Wang (2001), the government has various ways of controlling the press at its disposal. This control could have led to a culture of fear among journalists, leading to self-censorship and rendering the code of ethics a toothless tiger (Peterson \& Krings, 2009). Another plausible cause could be because Chonko et al.'s (2003) study was conducted in the context of direct sellers whereas this study focused on journalists.

From the perspective of journalists' professionalism, our results showed that there is significant positive relationship between professionalism and idealism but no significant negative relationship between professionalism and relativism. This implies that the more idealistic journalist tends to adhere to his/her professional code of ethics than his/her more relativistic counterpart. This finding partially corroborated Borten's (2000) findings that differences in allegiance to the profession and the news organization led journalists towards different behavioural strategies for resolving the dissonance of varying situations. For journalists strongly aligned to professional ideals, their strategies will likely be 
more directly confrontational towards their organization's expectations and less responsive to its social pressures.

Hence, in general, this study manifests that journalists with higher idealism and lower relativism scores will probably be more inclined to apply the codes of ethics compared to their counterparts with higher relativism and lower idealism scores.

Based on the test of difference results in Tables III and IV, this study shows that there is no significant difference among journalists from different language dailies as well as from different education backgrounds in terms of their idealistic and relativistic viewpoints. This implies that respondents' profile variables such as type of language daily and type of education medium have no impact on journalists' moral philosophies or personal values. It is probable that journalists, regardless of their ethnicity or religious backgrounds have learnt to exercise self-restraint and to operate within the system to avoid sanctions from the government under the Printing Presses and Publication Act 1984 (PPPA), Internal Security Act 1960 (ISA), Official Secret Act 1972 (OSA), Broadcasting Act 1998 and Sedition Act 1948.

\section{Implications and Recommendations}

A critical implication of this study is that relativist journalists are lacking in awareness of their journalistic code contents and hence less likely to apply the journalistic code of conduct in their daily activities compared to idealist journalists. This will be detrimental to achieving a fact-based and responsible news reporting, thus rendering the role of news organizations as watchdog ineffective. This will have serious repercussions on the National Integrity Plan and the government's effort in fighting corruption which constitutes one of the key areas that needs to be monitored.

It is apparent that fundamental differences in ethical ideologies had created skepticism among researchers with regard to formulating a moral code that is acceptable to all in a company, an industry or globally (Davis et al., 1998). In any case, the communication and enforcement of high ethical standards can provide many benefits (Singhapakdi et al., 1999) which include reduced penalties (Ferell et al., 1998), increased job satisfaction and employee commitment and hence increased performance (Hunt et al., 1989). As Paine (1994) had aptly put it "creating a climate that encourages exemplary conduct may be the best way to discourage misconduct".

As such, to ensure that the Journalistic Code of Ethics in Malaysia does not remain a toothless tiger, it is recommended that:

- Chief Editors of dailies display effective leadership to foster a corporate culture in which journalists with different ethical orientations (e.g. idealists and relativists) can exercise their roles as adversarial watchdogs (Wang, 2001);

- Dailies conduct ethical training focusing on three main areas as suggested by Chonko et al. (2003): (i) introduction of journalists to ethical theories; (ii) the exposure of journalists to ethical problems, and (iii) the mandate to instil a critical thinking and examination mindset regarding ethics situations;

- Dailies use of Forsyth's (1980) relativism - idealism scale as a selection tool to hire journalists; and

- Dailies provide reward and recognition to those journalists who show exemplary ethical conduct to perpetuate the required ethical behaviour.

If the above recommendations are effectively adopted, it will boost the professionalism and credibility of Malaysian journalists' in line with the National Integrity Plan, which emphasizes trustworthiness, transparency and accountability.

\section{Concluding Remarks, Limitations and Suggestions for Future Research}

Regardless of their ethical or ideological stance, Malaysian journalists should practice the Journalistic Codes of Ethics at all times in their news reporting for the good of the nation and public at large. To 
overcome the ethical dilemmas that they are currently facing, idealist journalists should not be subjected to political pressures to compromise their personal values and behave unprofessionally. Relativist journalists, on the other hand, should take cognizance of the contents of their ethics code, consider the code's usefulness and be more professional in their news reporting.

The main limitation of this study is that our convenience sample comprised journalists from only two states in Peninsular Malaysia viz. Ipoh and Penang. Hence, the findings are not generalizeable to all journalists in Malaysia. Besides, the respondents might be providing socially desirable answers to the survey questions due to the sensitive nature of this research.

The research should be replicated to cover a representative sample of all Malaysian journalists in both Peninsular Malaysia as well as East Malaysia (Sabah and Sarawak) and the findings should be collaborated to those found in this study.

In addition, other variables like organizational culture, industry culture, organizational communication and commitment should also be taken into account in future research.

\section{References}

Abaya, AC 2006, Freedom of Depress. Standard Today, March 16 issue.

Abbot, A 1988, The System of Professions: An Essay on the Division of Expert Labour. Chicago: (University of Chicago Press).

Adam, MA \& Rachman-Moore, D 2004, 'The methods used to implement an ethical code of conduct and employee attitude', Journal of Business Ethics, vol. 54, pp. 225-244.

Barnett. T, Bass, K. \& Brown, G 1994, 'Ethical ideology and ethical judgment regarding ethical issues in business', Journal of Business Ethics, vol. 13 (6), pp 469-480.

Bass, K, Barnett, T \& Brown, G 1998, 'The moral philosophy of sales managers and its influence on ethical decision making', Journal of Personal Selling and Sales Management vol. 18, pp 1-17.

Berkowitz 1994, "Work Roles"; Bertowitz, Allen \& Beeson, Exploring Newsroom Views; John McManus, Market Driven Journalism: Let the Citizen Beware? (Thousand Oaks, CA: Sage).

Borten 2000, 'A model for evaluating journalist resistance to business constraints', Journal of Mass Media Ethics, vol. 15 (3), pp 159-166.

Casel, C, Johnson, P \& Smith, K 1997, 'Opening the black box: Corporate codes of ethics in their organizational context', Journal of Business Ethics, vol. 16, pp. 1077-1093.

Chandra Muzaffar 1986, 'Freedom in Fetters: An analysis of the state of democracy in Malaysia', Aliran Kesedaran Negara, pp 158-164.

Christians, CG, 1995, 'Review essay: current trends in media ethics', European Journal of Communication, vol. 10 (December), pp 454-548.

Chonko, LB, Wotruba, TR. \& Loe, TW 2003, 'Ethics code familiarity and usefulness: Views on idealist and relativist managers under varying conditions of turbulence', Journal of Business Ethics, vol. 42, pp 237-252.

Davis, MA, Johnson, NB \& Ohmer, DG 1998, 'Issues - contingent effects on ethical decision-making: A cross-cultural comparison', Journal of Business Ethics, vol. 17 (4), pp 373-389.

Dean, PJ 1992, 'Making codes of ethics "real”", Journal of Business Ethics, vol. 11 (April), pp 285295.

Ekin, MG \& Tezolmez, SH 1999, 'Business ethics in Turkey: An empirical investigation with special emphasis on gender', Journal of Business Ethics, vol. 18, pp 17-34.

Etheredge, JM 1999, 'The perceived role of ethics and social responsibility: An alternative scale structure', Journal of Business Ethics, vol. 18, pp 51-64.

Ferrell, OC, LeClaire, DT \& Ferrell, L 1998, 'The Federal Sentencing Guidelines: A frame work for ethical compliance', Journal of Business Ethics, vol. 17 (March), pp 353-363.

Fisher, C 2001, 'Managers' perceptions of ethical codes: Dialectics and dynamics', Business Ethics A European Review, vol. 10(2), pp. 145-156.

Ford, RC \& Richardson, WD 1994, 'Ethical Decision Making: A Review of the Empirical Literature', Journal of Business Ethics, vol. 13, pp. 203-221.

Forsyth.DR 1980, 'A taxonomy of ethical ideologies', Journal of Personality and Social Psychology, vol. 39 (July), pp 175-184. 
Forsyth, DR 1981, 'Moral judgment: The influence of ethical ideology', Personality and Social Psychology Bulletin, vol. 7, pp 218-223.

Forsyth, DR, Nye, JL \& Kelley, K 1988, 'Idealism, relativism and the ethic of caring', Journal of Psychology vol. 122 (September), pp 243-248.

Forsyth, DR \& Berger, RE 1992, 'The effects of ethical ideology on moral behaviour', Journal of Social Psychology, vol. 117 (June), pp 53-56.

Harcup, T 2002, 'Journalists and ethics: The quest for a collective voice', Journalism Studies, vol. 3(1), pp. 101-114.

Hunt, SD \& Chonko, LB 1985, 'Ethics and marketing management: An empirical examination', Journal of Business Research, vol. 13, pp 339-359.

Hunt, SD, Wood, VR \& Chonko, LB 1989, 'Corporate ethical values and organizational commitment in marketing', Journal of Marketing, vol. 53 (July), pp 79-90.

Kaptein, M 2004, 'Business codes of multi-national firms. What do they say?', Journal of Business Ethics, vol. 50 pp. 13-31.

Leo, TW, Ferrell, L \& Mansfield, P 2000, 'A review of empirical studies assessing ethical decision making in business', Journal of Business Ethics, vol. 25, pp. 185-204.

Maes, JD, Jeffrey, A \& Smith, TV 1998, 'The American Association of Advertising Agencies (4As) Standards of Practice: How far does this professional association's code of ethics' influence reach?', Journal of Business Ethics, vol. 17, pp 1155-1161.

Marshall, RL, Armstrong, RW \& Smith, M 1998, 'The ethical environment of tax practitioners: Western Australian evidence', Journal of Business Ethics, vol. 17, pp 1265-1279.

Marta, JM, Singhakapdi,. \& Higgs-Kleyn, N 2001, 'Corporate ethical values in South Africa', Thunderbird International Business Review, vol. 43, pp775-772.

McDonald, G 2000, 'Business ethics: Practical proposal for organizations', Journal of Business Ethics, vol. 19, pp 143-158.

McNanus, J H 1997, 'Who is responsible for journalism?', Journal of Mass Media Ethics, vol. 12, pp. $5-17$.

Morris, MH, Marks, AS, Allen, JA \& Perry, NS Jr. 1996, 'Modeling ethical attitudes and behaviours under conditions of environmental turbulence: The case of South Africa', Journal of Business Ethics, vol. 15, pp 1119-1130.

Musa, BA \& Domatob, JK 2007, 'Who is a development journalist? Perspectives on media ethics and professionalism in Post-Colonial Societies', Journal of Mass Media Ethics, vol. 22(4), pp 315-331.

O'Dwyer, B \& Madden, G 2006, 'Ethical codes of conduct in Irish companies: A survey of code content and enforcement procedures', Journal of Business Ethics, vol. 63, pp. 217-236.

Paine, LS 1994, 'Managing for organizational integrity', Harvard Business Review, vol.72 (MarchApril), pp 106-117.

Peterson, LE \& Krings, F. 2009, 'Are Ethical Codes of Conduct Toothless Tigers for Dealing with Employment Discrimination?', Journal of Business Ethics, vol. 85, pp. 501-514.

Porter, WE 1968, 'Journalism', International Encyclopedia of Social Sicences, vol. 8, pp 265-272.

Schlenker, BR \& Forsyth, DR 1977, ,On the ethics of psychological research', Journal of Experimental Social Psychology, vol. 13 (September), pp 369-396. (2003).

Schwartz, M 2000, 'Why ethical codes constitute an unconscionable regression', Journal of Business Ethics, vol. 23, pp. 174-184.

Schwartz, M 2001, 'The nature of the relationship between corporate codes of ethics and behaviour', Journal of Business Ethics, vol. 32 (3), pp. 247-262.

Sekaran, U 2000, Research Methods for Business: A Skill Building Approach, $4^{\text {th }}$ Edition, (New York: John Wiley \& Sons).

Sims, RR 1991, ' The institutionalization of organizational ethics', Journal of Business Ethics, vol. 10, pp 493-506.

Singhapakdi, A \& Vitell, SJ 1992, 'Marketing ethics: Sales professionals versus other marketing professionals', Journal of Personal Selling \& Sales Management, vol. 12 (2), pp 27-38.

Singhapakdi, A, Vitell, SJ \& Kraft KL 1996, "Moral intensity and ethical decision making of marketing professionals', Journal of Business Research, vol. 36, pp 245-255. 
Singhakapdi, A, Kraft, KL, Vitell, SJ \& Rallapalli, KC 1999, ' The perceived importance of ethics and social responsibility on organizational effectiveness: A survey of marketers', Journal of Academy of Marketing Science, vol.23 (Winter), pp 49-56.

Somers, MJ, 2001, 'Ethical codes of conduct and organizational context: A study of the relationship between codes of conduct, employee behaviour and organizational values', Journal of Business Ethics, vol. 30, pp. 185-195.

Stead, WE, Worrell, DL \& Stead, JG 1990, 'An integrative model for understanding and managing ethical behaviour in business organizations', Journal of Business Ethics, vol. 9 (March), pp 233242.

Stevens, B 2008, 'Corporate ethical codes: Effective instrument for influencing behaviour', Journal of Business Ethics, vol. 78, pp. 601-609.

Steven Gan. Virtual democracy in Malaysia: Putting press freedom on the front banner, presented at the symposium: Beyond Media Education by World Association for Christian Communication' at Manila, Philippines, September 20-25 2002.

Strutton, DJ, Hamilton, B \& Lumpkin, JR 1997, 'An essay on when to fully disclose in sales relationships: Applying two practical guidelines for addressing truth-telling problems', Journal of Business Ethics, vol. 16, pp 545-560.

Svensson, G \& Wood, G 2008, 'A model of business ethics', Journal of Business Ethics, vol. 77, pp. 303-322.

Tansey, R., Brown, G, Hyman, MR \& Dawson, LE, Jr. 1994, 'Personal moral philosophies and the moral judgments of sales people', Journal of Personal Selling and Sales Management, vol. 14 (Winter), pp59-75.

Tsalikis, J \& Fritzsche DJ, 1989, 'Business ethics: A literature review with a focus on marketing ethics', Journal of Business Ethics, vol. 8 (9), pp 695-744.

Trevino, LK 1990, 'A cultural perspective on changing and developing organizational ethics', Research in Organization Change and Development, vol. 4, pp 195-230.

Trevino, LK, Weaver, GR, Gibson, D \& Toeffler, BL, 1999, 'Managing Ethics and Legal Compliance: What Works and What Hurts?', California Management Review 41 (2), 131-151.

Trevino, LK \& Weaver, D 2003, Managing Ethics in Organizations. (Stanford University Press, Stanford).

Vitell, SJ, Lumpkin, JR \& Rawwas, MYA, 1991, 'Consumer Ethics: an Investigation of the Ethical Beliefs of Elderly consumers', Journal of Business Ethics, vol. 10, pp. 365-375.

Vitell, SJ \& Encarnacion, RH 2006, 'The impact of corporate ethical values and enforcement of ethical codes on the perceived importance of ethics in business: A comparison of U.S. and Spanish managers. Journal of Business Ethics, vol. 64, pp. 31-43.

Wang, LK 2001, 'Media and democracy in Malaysia', Journal of Mass Media, vol. 8 (2), pp 67-88.

Weeks, WA \& Nantel, J 1992, 'Corporate codes of ethics and sales force behaviour: A case study', Journal of Business Ethics, vol. 11, pp 753-760.

Wong, K 2004, 'Asian-based development journalism and political elections: Press coverage of the 1999 General Election in Malaysia', Gazette vol. 66(1), pp. 25-40.

Wotruba, T R 1995, 'A Comprehensive Framework for the Analysis of Ethical Behavior with a Focus on Sales Organizations', Journal of Personal Selling and Sales Management, 10 (Spring), pp. 2942.

Wotruba, TR, Chonko, LB \& Loe, TW 2001, 'The impact of ethics code familiarity on manager behaviour', Journal of Business Ethics, vol. 33 (September).

www.NUJM.org 